\title{
ATTITUDE OF YOUTH ABOUT HIV / AIDS PREVENTION AT SMA 4 KOTA BATAM
}

\author{
Haivan Kusuma Aji ${ }^{1}$, Agung Hadi Pramono ${ }^{2}$ \\ haivankusumaaji@univbatam.ac.id ${ }^{1}$, agunghadipramono@univbatam.ac.id ${ }^{2}$ \\ Medical Education Study Program, Faculty of Medicine, Batam University ${ }^{1}$ \\ Doctor's Professional Study Program, Faculty of Medicine, Batam University ${ }^{2}$ \\ Jl. Uniba No. 5, Batam Center
}

\begin{abstract}
Background : According to the World Health Organization (WHO) HIV continues to be a public health problem globally, having claimed more than 35 million lives so far. In Indonesia since the beginning of the HIV-AIDS epidemic, nearly 78 million people have been infected with HIV and around 39 million people have died due to HIV. Adolescence is easily carried over to bad things such as smoking, having sex, drugs, or free sex and low levels of it. reproductive health knowledge including HIV / AIDS. The purpose of this study was to determine adolescent attitudes about HIV / AIDS prevention.
\end{abstract}

Method : This study used a descriptive research design. The length of the study was 6 months with a population of all class X and XI students of SMA N 4 Batam as many as 353 students, the sampling was systematic random sampling with a sample size of 77 respondents. The research instrument used a questionnaire.

Result : Research results Adolescents have a positive attitude as many as 50 respondents $(64.9 \%)$ and 27 respondents $(35.1 \%)$ have a negative attitude.

Conclusion : The conclusion is that more than half of the respondents are positive. Suggestions for the school it is suggested to be able to collaborate with the BKKBN or puskesmas to establish reproductive health services for adolescents in schools, especially on how to prevent HIV / AIDS so that early students have good attitudes and behavior towards HIV / AIDS.

Keywords: Attitude, HIV / AIDS

\section{INTRODUCTION}

Human Immunodeficiency Virus (HIV) is a virus that causes AIDS, which belongs to the retrovirus group. This virus attacks the human immune system which as a result can be susceptible to AIDS (Acquired Immuno Deficiency Syndrome). AIDS is a collection of disease symptoms or syndromes that are acquired due to decreased immunity caused by HIV (Kumalasari and Andhyantoro, 2012).

HIV / AIDS is also a very dangerous infectious disease because it not only has a negative impact on physical health, but people with HIV / AIDS also experience psychosocial problems, because of the public opinion that HIV / AIDS is transmitted through sexual relations outside of marriage. considered immoral and shameful. Such assumptions tend to discriminate against PLWHA, such as being excluded from the community and family environment, being humiliated and judged and refusing to get education for school children (Setyoadi and Endang, 2012)

he problem of HIV / AIDS is a health problem that is of concern because every year the cases continue to increase. According to the World Health Organization (WHO) HIV continues to be a public health problem globally, having claimed more than 35 million lives so far. In 2015, 1.1 (940 000-1300000) million people have died due to being infected with the HIV virus. There were approximately 36.7 (34.039.8) million people living with HIV at the end of 2015 with 2.1 (1.8-2.4) million people newly infected with HIV in 2015. Globally, Sub Sahara Africa is the most affected region, with 25.6 (23.1-28.5) million people living with HIV in 2015 (WHO 2015). In Indonesia since the 
beginning of the HIV-AIDS epidemic, nearly 78 million people have been infected with HIV and around 39 million people have died from HIV.

According to the Director General of Education Quality Improvement and Education Personnel (PMPTK) of the Ministry of National Education (2011), said that around 10,000 people living with HIV / AIDS in Indonesia half or 5,000 of them are junior high school / high school students. Data obtained from UNAIDS (United Nation for AIDS) at the end of 2007 states that young people in the world today live side by side with HIV / AIDS because some of the new HIV / AIDS cases have attacked adolescents aged 15-24 years. It is reported that every 14 seconds, one teenager is infected with the HIV / AIDS virus. Every day around 6,000 people aged 15-24 years are registered as new HIV sufferers. Most of the HIV / AIDS infection $(>80 \%)$ is suffered by the productive age group (15-49 years), especially men, but $20 \%$ of adolescents from the total population of Indonesia are more involved in risky behavior due to factors such as poverty, change social, and media influence. The attack of the productive age is a challenge that needs to be addressed immediately considering that the productive age is a price development asset (BKKBN, 2011).

Based on data from the Riau Islands provincial health office, it can be seen that the detection of HIV cases was mostly found in males, which is more than $50 \%$ of cases. HIV cases in men of detected age, the proportion of the most infected age group is the age group 25-49 years, while for AIDS cases the proportion of the most infected age group is the 20-24 year age group this means that from the time they are infected to the AIDS is 5 years old, then the age at infection is around 15-24 years (Riau Islands Health Profile, 2015).

Adolescence is one of the periods of human development. This period is a period of change or transition from childhood to adulthood which includes: physical, behavioral, biological and emotional changes. Behavior is a response or reaction to a stimulus (external stimuli). Changes in inappropriate behavior can lead to a high incidence of HIV / AIDS in adolescents (6). The causes of HIV / AIDS in adolescence are adolescents who become drug addicts, especially injection needle users, lack of knowledge about information on reproductive health, free sex, HIV / AIDS and other infections caused by sex. The lack of information obtained by adolescents about reproductive health has an impact on their knowledge of reproductive health.

Rahmati's (2014) research results regarding the relationship of knowledge about HIV / AIDS with attitudes towards prevention in class $X$ and XI students at SMA Taman Madya Jetis Yogyakarta towards 50 respondents. The results showed that students had high knowledge (48\%), while the attitudes of students towards HIV / AIDS prevention were mostly sufficient (66\%).

Attitude is always associated with behavior that is within the limits of reasonableness and normality which is a response or reaction to a stimulus (Muhamad et al. 2015). Knowledge is also a reinforcing factor for changes in attitudes, knowledge and attitudes which will be the basis for moral formation in a person, meaning that there is harmony between knowledge and attitudes, where attitudes are formed after the process of knowing first occurs. According to Muhammad's (2015) research on the relationship between the level of knowledge and attitudes about HIV / AIDS in SMA Negeri 1 Karang Tengah Demak, most respondents already have a good level of knowledge and have a supportive attitude towards HIV / AIDS prevention, namely (93.3 $\%)$ and those who have poor knowledge $(6.7 \%)$ while respondents who have a non-supportive attitude have a higher percentage of respondents who are less good $(33.3 \%)$ compared to respondents who have good knowledge, namely (6.7 \%).

Based on the description of the background above, the researchers are interested in conducting a study entitled Youth Attitudes about HIV / AIDS Prevention

\section{RESEARCH PURPOSES}

This study aims to determine the attitudes of adolescents towards HIV / AIDS prevention in SMAN 4 Batam City

\section{RESEARCH METHODS}

This study used a descriptive research design. The length of the research was 6 months with a 
population of all class $\mathrm{X}$ and XI students of SMA N 4 Batam as many as 353 students, the sampling was systematic random sampling with a sample size of 77 respondents. The research instrument used a questionnaire

\section{RESEARCH RESULT}

From the research results, it was found that the majority of respondents' characteristics were female, namely as many as 53 people $(68.8 \%)$ and 24 people $(31.2 \%)$ male - male, seen from age, as many as 36 people $(46.7 \%)$ were 16 years, 38 people $(49.4 \%)$ were 17 years old and 3 people (3.9\%) were 18 years old.

Research results Adolescents have a positive attitude as many as 50 respondents (64.9\%) and 27 respondents $(35.1 \%)$ have a negative attitude

\section{DISCUSSION}

From the results of the study, it can be seen that most of the respondents had a positive attitude towards HIV / AIDS as many as 50 respondents $(64.9 \%)$, and a small proportion of respondents had negative attitudes towards HIV / AIDS as many as 27 respondents (21.1\%). Based on these data, some respondents who have a positive attitude about HIV / AIDS can be seen from the response of students who are loyal to their partner to prevent the risk of HIV / AIDS transmission by 73 respondents $(94.8 \%)$, while most respondents have a negative attitude by stating that drug and alcohol use is not risk factors for HIV / AIDS transmission because they cannot cause deviant behavior (92.2\%).

Educational experts say that adolescents are those aged 13 to 18 years, where someone has passed childhood but is still not mature enough to be considered an adult (Mubarak, 2009). According to Meliono and Irmayanti (2007) in module 1 of the integrated personality development course, age affects a person's level of knowledge. As the age increases, the experience they have is also more numerous and varied. The more mature a person is, the level of one's knowledge will be more mature or better in thinking and acting

Behavior formation is based on positive knowledge and attitudes. Determination of a positive attitude, knowledge always plays an important role. High knowledge is very influential on a person's attitude. A teenager who has a positive attitude is due to having high knowledge so that the teenager can distinguish between positive and negative attitudes in acting. One of the good actions is being able to respond to the prevention of HIV / AIDS that occurs in adolescents

At the age of adolescence, boys and girls experience physical development. Physical development occurs in all organs of the body, including sexual. In the sexual organs there is an increase in growth hormone levels, especially sex hormones in both male and female adolescents which will cause changes in overall sexual behavior. According to Manuaba (2009) in understanding female reproduction, there are two factors that underlie sexual behavior in adolescents, namely early marriage and the speed of information flow that can lead to sexual stimulation in adolescents. The results of this study are in accordance with Irnawati's (2011) theory of 9 health tips which states that health culture is much more accessible to women, so that women are generally better at knowledge of their health than men.

The respondent's attitude towards HIV / AIDS is a picture that shows the student's response to statements relating to their views, feelings and tendencies to take action against HIV / AIDS. Knowledge, attitudes and beliefs are the main factors for changes in a person's health behavior.

Attitudes are based on the evaluative process within the individual towards an object. The response will arise when the individual is faced with a stimulus that requires a reaction to individual behavior.

The attitude that the respondent had was related to HIV / AIDS prevention efforts, where the results of the study showed that the higher the respondent's attitude, the higher the HIV / AIDS prevention efforts.

According to Chave, Bogardus, LaPieree, Mead, and Gordon Allport in Azwar 2013, attitude is a kind of readiness to react to an object in a certain way when an individual is faced with an object that requires a response. Research conducted by Sambono (2013) on the study of the behavior of Ronevan Tual high school students towards HIV / AIDS prevention in Dullah Selatan Subdistrict, Tual City, stated that most of the students had positive attitudes as many as 91 people (65\%), while those with 
negative attitudes were as many as 91 people (65\%). 49 people $(35 \%)$

This research is in line with the research conducted by Rupilu (2013) entitled "The Relationship between Knowledge and Attitudes about HIV / AIDS and HIV / AIDS Prevention Measures in Students at SMA Negeri 1 Tual in 2013". The results of this study indicate that attitudes are things that affect HIV / AIDS prevention measures, most of the respondents' attitudes had a significant influence on HIV / AIDS prevention measures. This can be seen from the significant results $p=0.000<0.05$

One of the factors that influence attitudes is the level of education. The level of education as a system has an influence in the formation of attitudes because it lays the foundation for understanding and moral concepts in individuals, understanding good and bad, the dividing line between what is allowed and what cannot be done, obtained from education and its ranks. The number of respondents who have a positive attitude is almost the same as those with high knowledge. This is because the respondent's knowledge has been accompanied by the respondent's readiness and desire to act to prevent HIV / AIDS.

The results of Setyarini's (2016) research on the relationship between adolescent knowledge about HIV / AIDS with HIV / AIDS prevention attitudes in SMA Negeri 1 Gurah Kediri Regency stated that most respondents had a very positive HIV / AIDS prevention attitude, namely $88.60 \%$. Sari's (2011) research on the description of knowledge, attitudes and behavior regarding HIV / AIDS in students of the Tanjung Pura University medical education program also shows that as many as $86.7 \%$ of respondents have high attitudes about HIV / AIDS

The results of this study are in line with research conducted by Ariyanto (2010) on the relationship between students 'knowledge about HIV / AIDS and students' attitudes towards HIV / AIDS in SMA Negeri 6 Kota Kupang with a sample size of 78 students who also got the results that respondents had a positive attitude. as many as 64 respondents $(82.1 \%)$ about HIV / AIDS.
Based on the discussion above, it was concluded that the attitudes of the students were mostly positive due to the amount of information they got. According to researchers, differences in attitudes in adolescents are influenced by the conditions of each individual, perspective and background. The more developed the mindset and the increased experience make the adolescent sort out what is good and what is bad for him so that an attitude is formed in the adolescent.

\section{CONCLUSION}

From the research results of 77 respondents, it can be concluded, namely: the majority are positive as many as 50 respondents (64.9\%)

\section{SUGGESTION}

\section{For students of SMAN 4 Batam}

SMAN 4 Batam students are expected to be more active in seeking information from print media, electronic media, health workers and others about HIV / AIDS and ways to prevent HIV / AIDS so that they can increase their understanding of HIV / AIDS and know how to correct prevention.

2. Share the research place

For schools it is suggested to be able to collaborate with BKKBN or puskesmas to establish reproductive health services for adolescents in schools, especially on how to prevent HIV / AIDS so that early students have good attitudes and behavior towards HIV / AIDS.

3. For Batam University Institutions

From the results of this study, it is hoped that it can provide benefits to add information about HIV / AIDS and can be used as library material.

4. For Further Researchers

It is hoped that further researchers will be able to further investigate HIV / AIDS by including other variables that have not been examined in this study, such as education, motivation, and adolescent behavior. And the researchers also really hope that the next researchers can research with a larger number of samples, a different place and a more precise design and more importantly can condition the time when researching. 


\section{DAFTAR PUSTAKA}

Andhyantoro Iwan, Kumalasari Intan, 2012. Kesehatan Reproduksi, Jakarta : Salemba Medika

Anggi (2015) Hubungan pengetahuan ibu hamil tentang perkembangan janin dengan sikap ibu hamil terhadap perkembangan janin. Karya tulis ilmiah tidak diterbitkan. Universitas Batam. Kepulauan Riau.

Fafi (2014) Hubungan tingkat pengetahuan tentang HIV/AIDS dengan sikap terhadap pencegahannya pada siswa kelas $x$ dan xI di SMA Taman Madya Jetis Jogyakarta. Karya tulis ilmiah tidak di terbitkan. Stikes Aisiyyah Yogyakarta.

Fauzan (2015) Pengetahuan sikap dan perawatan diri klien dengan rematik yang tinggal di wilayah puskesmas Muaro Bodi Kecamatan IV Nagari Kabupaten Sijunjang Sumatra Barat. Skripsi tidak diterbitkan. Universitas Sumatra Utara.

Kementrian kesehatan RI, 2014. Pedoman Penerapan Terapi HIV Pada Anak. Jakarta.

Maria (2015) Beberapa faktor resiko yang berpengaruh terhadap kejadian HIV/AIDS pada lelaki umur 25-44 tahun di kota Dili Timor Leste. Tesis tidak di terbitkan. Universitas Di Ponogoro Semarang

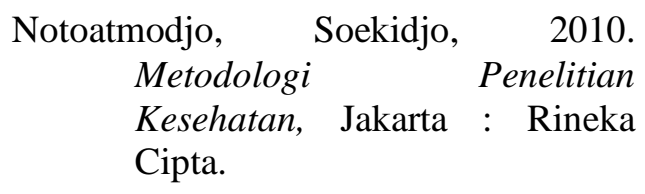

Novika (2012) Hubungan pengetahuan dan sikap remaja tentang HIV/AIDS di SMA Negeri 1 Medan. Skripsi tidak di terbitkan. Universitas Sumatra Utara.

Setyoadi, Triyanto Endang, 2012 Strategi Pelayanan
Keperawatan Bagi Penderita AIDS, Graha Ilmu.

Selfya (2014) Hubungan antara tingkat pengetaahuan ibu tentang kontrasepsi suntik DMPA dengan kepatuhan jadwal penyuntikan ulang di Puskesmas Sukaramai. Karya tulis ilmiah tidak di terbitkan. Universitas Sumatra Utara

Sumiyati (2013) Hubungan tingkat Pengetahuan dan sikap masyarakat terhadap upaya pencegahan penyakit Tuberkolosis Di RW 04 Kelurahan Lagoi Jakarta Utara. Sripsi tidak di terbitkan. Universitas Islam Negeri Syarif Hidayatullah

Vera (2015) Hubungan dukungna sosial keluarga dengan tingkat depresi pada pasien HIV/AIDS(ODHA) Di rumah Sakit Kemuliaan. Skripsi tidak di terbitkan. Universitas Batam. Kepulauan Riau.

dinkesriau.net/downlot.php?...Profil\%2 OKesehxatan\%20Provinsi\%20Ria u\%20Tahun\%2015.Diakses tanggal 18 Maret 2017

http://www.depkes.go.id/resources/down load/pusdatin/profil-kesehatanindonesia/profil-kesehatanIndonesia-2015. Diakses tanggal 11 Maret 2017

http://Dwi.2014eprints.ums.ac.id/30909/ 19/2_NASKAH_PUBLIKASI.

Gambaran Sikap Dan Dukungan Keluarga Terhadap Penderita Gangguan Jiwa Di Wilayah Kecamatan Kartasura. Diakses tanggal 30 Maret 2017

http://niasariayuningsih.ejournal2014.u nsrat.ac.id/index.Pengaruh penyuluhan tentang HIV/AIDS terhadap pengetahuan dan sikap siswa di SMA Negeri 1. Diakses tanggal 1 April 2017

http://perpusnwu.web.id/karyailmiah/do cuments/4419.Hubungan antara 
ZONA KEDOKTERAN - Vol. 10 No. 3 September 2020

tingkat pengetahuan dengan sikap tentang HIV/AIDS 2015. Diakses tanggal 13 Maret 2017

https://rahmahadati.files.wordpress.com 2015/09/isi. Pengaruh penyuluhan kesehatan terhadap pengetahuan siswa tentang HIV/AIDS. Diakses tanggal 23 Maret 2017

https://ariyantomediakesehatanmasyarakat.file s.wordpress.com/2012/06/jurnal. Hubungan antara pengetahuan siswa tentang penyakit HIV/AIDS dengan sikap siswa terhadap penyakit HIV/AIDS di SMAN 6 Kupang 2010. Diakses tanggal 01 Agustus 2017 